\title{
STABILITY OF LAND STRUCTURE OF AGRICULTURAL PROPERTIES SOLD BY THE AGENCJA NIERUCHOMOŚCI ROLNYCH IN SZCZECIN
}

\author{
Iwona Foryś, assoc. prof., PhD. \\ Department of Econometrics and Statistics \\ University of Szczecin \\ e-mail:forys@wneiz.pl \\ Ewa Putek-Szeląg, PhD. \\ Department of Econometrics and Statistics \\ University of Szczecin \\ e-mail:wicheru@wneiz.pl
}

\begin{abstract}
Trading in agricultural land in the Zachodniopomorskie Voivodeship (a high-level administrative subdivision of Poland) is strictly connected with the local activity of the ANR (Agencja Nieruchomości Rolnych - Agricultural Market Agency), which is the effect of historical problems concerning the ownership of arable land left over from the communist era. In effect, the Polish State Treasury is still in charge of managing state-owned farmland and, therefore, plays an important role in shaping local agricultural land markets.

The study includes all the sale transactions concluded by the Szczecin division of the ANR in the Zachodniopomorskie gminas. The subjects of the study are lands described by quantitative variables, such as: property size, location, date of sale and sale price. The purpose of the study was to define the structure of agricultural land sold by the ANR. The authors verified their research hypothesis concerning the stability of land structure over time of the agricultural land being sold.
\end{abstract}

Keywords: agricultural, agricultural land, stability of structure.

JEL Classification: C01.

Citation: Foryś I., Putek-Szeląg E., (2013), "Structure stability of agricultural lands of the real estate sold by the APA (Agencja Nieruchomości Rolnych) in Szczecin", Real Estate Management and Valuation, vol. 21, no. 2, pp. 45-55.

DOI: $10.2478 /$ remav-2013-0016.

\section{Introduction}

A buyer's decision to purchase agricultural property can be influenced by various factors, depending on their individual preferences as well as the situation on the market. However, the most important criterion of a decision to purchase a given piece of property is its location. As early as in 1826-1850, von Thünen noted in his location theory that economic rent depended on the location of a farm and its productivity (BLAUG 1994). Other objective factors that determine the buyers' decisions include the accessibility of a plot as well as its typical features such as valuation class, physical landscape or agricultural condition (CYMERMAN 2011). In view of the production potential, other vital factors are environmental pollution and drainage facilities. Location often determines other, both physical and legal, attributes of the property and its environment. It indicates what land use policy or specific 
functions can be expected in the area, if the land is easily accessible or what its market position is. There are also subjective factors that make the property more attractive for an individual investor. Often the buyer's decision is additionally conditioned by their risk-seeking tendency and expectations concerning a future rise in property value. Prices of land tend to rise in regions that are more advanced in farming, in the proximity of densely populated centers, which is in agreement with the location theory and the lower costs of sales (FORYŚ 2005).

Due to its production potential, the value of any agricultural property grows when the access road is of good quality, as this is necessary for farmers who use heavy agricultural vehicles or transport their produce to the market. The most common categories of roads are paved and dirt roads. The economic results of farming production, especially the kind requiring heavy machinery, largely depend on the shape of the plot and its physical landscape. The costs of operating machinery are higher on plots that have an irregular shape and those that are too narrow or steep (their value is lessened by land erosion), or located in undulating areas or areas with a poor subsurface and hydrological conditions. Agricultural machinery operating in such conditions has to work longer and is less efficient. It is also more weather-dependent. It is generally assumed (CYMERMAN 2011) that the most disadvantageous plot shape is a polygon the angles of which differ from a right angle by more than 30 degrees. The authors emphasize the importance of drainage systems in the farming process. Other obstacles limiting the right to use a given piece of land properly are technical infrastructure facilities (such as transmission lines and pylons, other facilities and the safety zones around them). Agricultural land can also be degraded by environmental factors.

In view of the above deliberations, the authors decided to verify a research hypothesis concerning the stability in time of the structure of arable land owned by the State Treasury and sold by the ANR in Szczecin. Additionally, they considered conducting a spatial analysis of the land sold by the ANR by clustering the gminas (the basic units of administrative division of Poland at its lowest uniform level) of the Zachodniopomorskie voivodeship according to the structure of the traded land.

\section{Research material}

According to the Civil Code, a piece of real estate is qualified as agricultural real estate when it is or can be used for the purpose of farming, such as plant and animal production (including vegetables, fruit and fish). However, first and foremost, the agricultural character of a piece of real estate must be stated in the relevant entry of a local Land Register which includes lists of agricultural lands and a land use plan and where arable lands are classified according to their purpose. In this paper, the authors adopted classification proposed by R. Cymerman et al (CYMERMAN at al. 2011, p.15) who, according to the Land and Property Register, divided land property into seven groups: agricultural land, forests, shrubland, built-up and urbanized areas, ecological arable land, land under water, miscellaneous land and wasteland. Agricultural land falls into the following categories: arable land, meadows, pastures, orchards, farm buildings, fish ponds, and drainage ditches. In addition, agricultural lands are subjected to soil quality evaluation in order to assess their usefulness for plant production and thus, divided according to their valuation class. Arable land soils fall into nine valuation classes, while soils of land under permanent pasture - into six (KONOWALCZUK, URBAŃCZYK 2000).

The study was conducted on a set of 17,662 land ownership transactions concluded by the ANR in 108 gminas in the Zachodniopomorskie Voivodeship in the period of 1995-2011. The authors used a database which, in further analyses, determined the type of classification of land in the traded real estate, even though it did not always compliment the above mentioned R. Cymerman's classification. As a result, the authors obtained a data series concerning the sale of a total of 191,529.26 ha in which individual observations were described by the following variables:

- the size of each plot of land (ha);

- the gmina where the sold property was located, within the Zachodniopomorskie voivodeship;

- the date of the transaction (yyyy-mm-dd);

- the transaction price (PLN);

- the transaction price of 1 ha (PLN/ha).

The authors decided against carrying out analysis according to land class due to the fact that the relevant 2005-2011 data had turned out to be incomplete. Instead, they used the ANR database because it contained the complete list of all transactions included in the period of study as well as a detailed structure (classification) of the land. They also took into consideration the position of the 
ANR on the market as a supplier of tradable land (including agricultural land) in the Zachodniopomorskie Voivodeship. Other sources of information did not allow for such a thorough and complete study of the seventeen-year-long time period. In the Zachodniopomorskie voivodeship, agricultural land in good farming condition constitutes $80.6 \%$ of the total agricultural area, while $69.3 \%$ of this land is cultivated ${ }^{1}$. Arable land predominated in the examined sample of transactions concluded in 1995-2011, (Table 1).

Table 1

The structure of cultivated land as part of real estate sold in the Zachodniopomorskie Voivodeship by the ANR in 1995-2011 (\%).

\begin{tabular}{|c|c|c|c|c|c|c|c|c|c|}
\hline \multirow{2}{*}{ Land type } & \multicolumn{9}{|c|}{ years of study } \\
\hline & 1995 & 1996 & 1997 & 1998 & 1999 & 2000 & 2001 & 2002 & 2003 \\
\hline arable land & 67.62 & 70.75 & 73.45 & 73.57 & 68.24 & 73.19 & 69.77 & 73.89 & 71.87 \\
\hline orchards & 4.55 & 2.09 & 2.68 & 1.19 & 1.07 & 1.06 & 2.59 & 2.65 & 2.33 \\
\hline meadows & 8.75 & 10.05 & 8.94 & 8.36 & 10.48 & 12.36 & 10.92 & 7.94 & 10.51 \\
\hline pastures & 8.31 & 8.35 & 7.32 & 9.14 & 10.18 & 5.68 & 8.19 & 7.52 & 9.12 \\
\hline forests & 0.35 & 1.19 & 0.91 & 0.69 & 1.11 & 0.92 & 0.52 & 0.98 & 0.77 \\
\hline shrubland & 1.97 & 0.81 & 1.06 & 1.83 & 2.96 & 1.77 & 1.48 & 1.97 & 1.22 \\
\hline standing water & 0.48 & 0.32 & 0.28 & 0.59 & 0.97 & 0.70 & 1.13 & 0.50 & 0.01 \\
\hline running water & 0.00 & 0.00 & 0.00 & 0.00 & 0.00 & 0.00 & 0.00 & 0.00 & 0.00 \\
\hline ditches & 0.69 & 0.35 & 0.41 & 0.34 & 0.46 & 0.37 & 0.26 & 0.23 & 0.29 \\
\hline wasteland & 7.27 & 6.10 & 4.94 & 4.30 & 4.53 & 3.95 & 5.15 & 4.32 & 3.88 \\
\hline total & 100 & 100 & 100 & 100 & 100 & 100 & 100 & 100 & 100 \\
\hline \multirow{2}{*}{ Land type } & \multicolumn{9}{|c|}{ years of study } \\
\hline & 2004 & 2005 & 2006 & 2007 & 2008 & 2009 & 2010 & 2011 & \\
\hline arable land & 79.17 & 78.77 & 71.91 & 73.95 & 80.38 & 79.50 & 79.14 & 77.72 & \\
\hline orchards & 0.09 & 0.16 & 0.57 & 0.19 & 0.46 & 0.12 & 0.01 & 0.17 & \\
\hline meadows & 8.68 & 8.80 & 14.84 & 14.20 & 7.53 & 9.68 & 8.69 & 10.02 & \\
\hline pastures & 5.67 & 5.82 & 6.43 & 4.79 & 5.44 & 4.29 & 5.62 & 4.44 & \\
\hline forests & 1.45 & 1.70 & 1.10 & 1.77 & 1.54 & 1.42 & 1.35 & 1.76 & \\
\hline shrubs & 0.94 & 1.19 & 1.34 & 1.41 & 1.12 & 1.35 & 1.49 & 2.04 & \\
\hline standing water & 0.21 & 0.03 & 0.13 & 0.11 & 0.10 & 0.10 & 0.01 & 0.06 & \\
\hline running water & 0.00 & 0.00 & 0.00 & 0.00 & 0.00 & 0.00 & 0.00 & 0.00 & \\
\hline ditches & 0.40 & 0.41 & 0.68 & 0.71 & 0.37 & 0.41 & 0.46 & 0.53 & \\
\hline wasteland & 3.39 & 3.12 & 3.00 & 2.88 & 3.05 & 3.14 & 3.22 & 3.26 & \\
\hline total & 100 & 100 & 100 & 100 & 100 & 100 & 100 & 100 & \\
\hline
\end{tabular}

Source: own study

The share of arable land in the total area of land sold by the ANR increased annually, from $67.62 \%$ in 1995 to $77.72 \%$ in 2011. The largest proportion of traded arable land was observed in 2008 (80.38\%) and stabilized at a high level for the next two years. The second most often sold type of land were meadows, with a share ranging from $7.39 \%$ to $14.84 \%$ of the total land traded in the individual years. Pastures reached similar levels, ranging from $4.44 \%$ to $10.18 \%$. Orchards, forests, ditches, shrubs, and lands under water constituted a small portion of the sold land, with a combined total of $10 \%$.

Since the proportion of arable land in the total area of sold real estate was so high and due to the fact that a variety of premium crops can be obtained from such land (particularly when the soil is of high quality) (KONOWALCZUK, URBAŃCZYK 2000), we can assume that it was the share of arable land that determined the price of the analyzed properties. That is why the authors decided to analyze transaction prices as well. Table 2 below shows the basic characteristics of the price of 1 ha of real estate sold by the ANR in 1995-2011.

\footnotetext{
${ }^{1}$ According to the Statistical Office in Szczecin, Użytkowanie gruntów, powierzchnia zasiewów i pogłowie zwierząt gospodarskich w województwie zachodniopomorskim. Powszechny Spis Rolny 2010, Szczecin, 2013.
} 
Half of the transactions concluded in 1995-2011 fluctuated in the price range of 1,500$15,500 \mathrm{PLN} /$ ha and $75 \%$ of the transactions were concluded at 4,000-28,600 PLN/ha, with $25 \%$ of the sales reaching merely 900 - approx. 12,000 PLN/ha (Table 2). In 1995-2011, the mean transaction price of one hectare did not increase steadily and oscillated significantly in a wide range of 10,000-58,000 PLN/ha. The analysis of median transaction prices shows that there were two growth periods, in 1995-2000 and 2006-2011, as well as a period of relative stability in 2001-2005. In the periods of growth, the prices demonstrated different dynamics. In the years 2006-2011 we can see a high annual increase of $36 \%$ of the transaction price median per one hectare which in 1995-2000 did not exceed $13 \%$. What is more, in 1995-2000 half of the transaction prices were not higher than 5,000 PLN/ha, in 2001-2006 they ranged from 6,000 to 6,700 PLN/ha, while in the period of 2007-2011 - from 9,000$15,400 \mathrm{PLN} / \mathrm{ha}$. When faced with such a significant asymmetry of price distribution in the subsequent years, the mean transaction price per hectare is not a good reference point. The mean price is a measure which is very sensitive to extreme observations, such as the extremely high prices of some agricultural land sales quoted above.

Table 2

Basic characteristics of the transaction price of land sold by the ANR in the Zachodniopomorskie voivodeship in 1995-20011 (PLN/ha).

\begin{tabular}{|c|c|c|c|c|c|c|c|c|c|}
\hline \multirow{2}{*}{ Year } & \multicolumn{9}{|c|}{ Years of study } \\
\hline & 1995 & 1996 & 1997 & 1998 & 1999 & 2000 & 2001 & 2002 & 2003 \\
\hline Mean & 9755 & 20157 & 28749 & 25306 & 20706 & 32735 & 17065 & 15834 & 14120 \\
\hline Median & 1536 & 2417 & 3955 & 4860 & 5019 & 6681 & 5516 & 5802 & 5513 \\
\hline Number & 342 & 635 & 531 & 680 & 464 & 267 & 720 & 776 & 827 \\
\hline Standard deviation & 32956 & 50997 & 59359 & 65504 & 66756 & 223363 & 39050 & 42534 & 33302 \\
\hline Min & 80 & 90 & 230 & 50 & 389 & 350 & 400 & 450 & 200 \\
\hline Max & 428571 & 544900 & 337383 & 678175 & 102285 & 352870 & 390597 & 617886 & 434343 \\
\hline Quartile I & 951 & 1415 & 2253 & 2554 & 3049 & 3259 & 3521 & 3798 & 3887 \\
\hline \multirow[t]{2}{*}{ Quartile III } & 4040 & 9029 & 11691 & 11465 & 10303 & 20738 & 11617 & 11161 & 10246 \\
\hline & \multicolumn{9}{|c|}{ Years of study } \\
\hline Year & 2004 & 2005 & 2006 & 2007 & 2008 & 2009 & 2010 & 2011 & \\
\hline Mean & 17733 & 30144 & 28014 & 58003 & 48602 & 47718 & 42117 & 43007 & \\
\hline Median & 5159 & 5909 & 6986 & 9285 & 13087 & 14075 & 14993 & 15396 & \\
\hline Number & 1203 & 1307 & 1403 & 1472 & 1341 & 1194 & 1526 & 1767 & \\
\hline Standard deviation & 48499 & 123150 & 95137 & 177508 & 121133 & 122726 & 90247 & 108485 & \\
\hline Min & 175 & 729 & 3094 & 32 & 2752 & 6135 & 4780 & 3313 & \\
\hline Max & 788000 & 239465 & 180924 & 234000 & 264000 & 201754 & 137131 & 233333 & \\
\hline Quartile I & 3602 & 4289 & 5555 & 6998 & 9527 & 11099 & 11751 & 11619 & \\
\hline Quartile III & 10933 & 13455 & 13467 & 27810 & 38011 & 27365 & 27867 & 28571 & \\
\hline
\end{tabular}

Apart from the time factor and economic situation, such a vast diversity of prices was the result of other factors as well. Particular attention should be paid to the location of land traded by the ANR and, consequently, to the areas that were homogeneous ${ }^{2}$ as far as the structure, the class of arable land and the price median of the real estate sold in the analyzed period. For the purpose of clustering the gminas, the authors used the cluster analysis and Ward's method along with Euclidean distance (Fig.2).

\footnotetext{
2 with the administrative area of a gmina as a unit
} 
Cluster analysis is the task of grouping a set of objects (gminas) that are similar to each other in terms of certain attributes. The method is used when a researcher lacks a priori hypothesis and is at the extrapolation stage of his or her study (GATNAR, WALESIAK, 2004). For their analysis, the authors selected those attributes that could strongly differentiate the objects, i.e., the examined structure of land properties and their transaction prices. By doing so, they were able to select clusters of gminas for more detailed analyses. Ward's method, which is based on the minimized sum of squares of within-cluster variance, is regarded as very effective. Euclidean distance is also a popular metric which is considered the most natural.

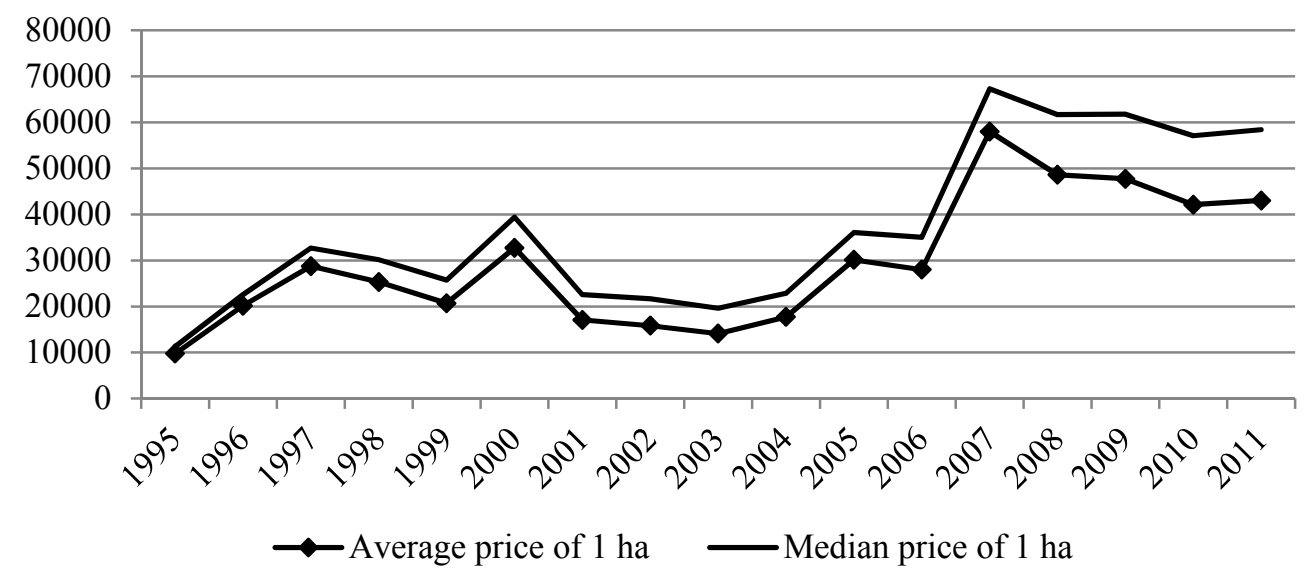

Fig.1. Dynamics of the transaction prices of land properties sold by the ANR in the Zachodniopomorskie voivodeship in Szczecin in 1995-2011 in PLN/ha). Source: own study based on the ANR database.

The clustering results presented in the dendrogram (Fig. 2) reveal a hierarchical structure of the set of objects (the gminas in the Zachodniopomorskie voivodeship where the ANR sold land properties) due to the decreasing similarity between them. At the same time, they unfold other smaller clusters of objects and provide grounds for interpretation. We can divide the clusters based on the large value of differences between subsequent nodes or using a graph of the course of agglomeration or the accessible measures.

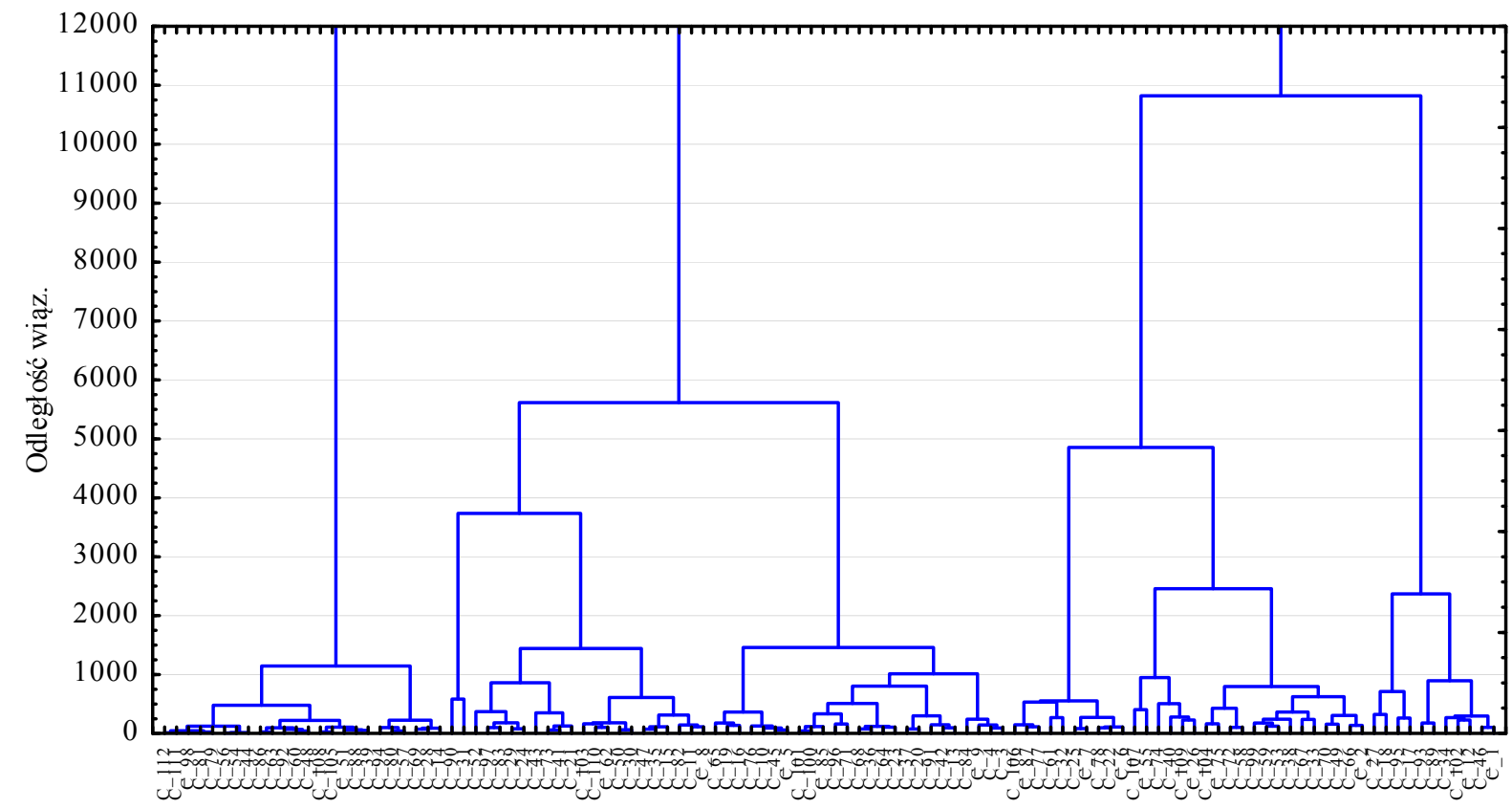

Fig. 2. Clustering of gminas according to the size of individual land properties. Source: own study based on the ANR database. 
The authors applied the former method and selected three groups of similar gminas, taking into consideration the largest differences between subsequent nodes (Table 3 ).

Table 3

The result of clustering the analyzed 108 gminas in the Zachodniopomorskie voivodeship.

\begin{tabular}{|c|c|c|}
\hline \multicolumn{3}{|c|}{ Name of gmina } \\
\hline Group 1 & Group 2 & Group 3 \\
\hline $\begin{array}{l}\text { BIELICE, BIERZWNIK, BOLESZKOWICE, BĘDZINO, } \\
\text { BIALOGARD, BIESIEKIERZ, BORNE SULINOWO, } \\
\text { CEDYNIA, CHOCIWEL, CZAPLINEK, CZEOPA, } \\
\text { DARŁOWO, DOBRA NOWOGARDZKA, DOBRA } \\
\text { SZCZECINSSKA, DYGOWO, GOLCZEWO, GOLENIÓW, } \\
\text { GRZMIACA, INSKO, KALISZ POMORSKI, KOBYLANKA, } \\
\text { KOŁBASKOWO, KOEOBRZEG, KOZIELICE, LIPIANY, } \\
\text { MALECHOWO, MARIANOWO, NOWOGRÓDEK } \\
\text { POMORSKI, OSINA, OSTROWICA, POLANÓW, } \\
\text { POSTOMINO, PRZYBIERNÓW, RABINO, SIANÓW, } \\
\text { SIEMYŚL, SEAWNO, SLAWOBORZE, STEPNICA, } \\
\text { SUCHAŃ, ŚWIERZNO, ŚWIERZYNO, TRZEBIATÓW, } \\
\text { TUCZNO, USTRONIE MORSKIE, ZLOCIENIEC }\end{array}$ & $\begin{array}{l}\text { BANIE, BARLINEK, BROJCE, BARNICE } \\
\text { BOBOLOCE, CHOJNA, CHOSZCZNO, DĘBNO, } \\
\text { DOBRZANY, DOLICE, DRAWNO, GOŚCINO, } \\
\text { GRYFICE, GRYFINO, KAMIEŃ POMORSKI, } \\
\text { KARNICE, KRZECIN, ŁOBEZ, MASZEWO, } \\
\text { MIESZKOWICE, MORYŃ, MYŚLIBÓRZ, } \\
\text { NOWOGARD, PELCZYCE, PLOTY, POŁCZYN- } \\
\text { ZDRÓJ, PRZELEWICE, PYRZYCE, RADOWO } \\
\text { MAŁE, RECZ, RESKO, STARA DABROWA, } \\
\text { STARGARD SZCZECINKSK, SZCZECINEK, } \\
\text { ŚWIDWIN, TRZCINKSO ZDRÓJ, TYCHOWO, } \\
\text { WAŁCZ, WĘGORZYNO, WIDUCHOWA, WOLIN }\end{array}$ & $\begin{array}{l}\text { BIALY BÓR, BRZEZNO, DZIWNÓW, } \\
\text { KARLINO, KOSTRZYN, LUBISZYN, } \\
\text { MANOWO, MIELNO, MIĘDZYZDROJE, } \\
\text { MIROSŁAWIEC, NOWE WARPNO, OKONEK, } \\
\text { POLICE, REWAL, RYMAŃ } \\
\text { SŁUPSK, STARE CZARNOWO, SZYDŁOWO } \\
\text { ŚWINOUJSCIE, WARNICE, WIERZCHOWO }\end{array}$ \\
\hline
\end{tabular}

Source: own study based on the ANR database.

Table 4 shows the selected characteristics of the three groups of similar gminas. The first and third groups contain those gminas where the ANR sold approximately $1 / 3$ of State Treasury land out of the total area traded by the Agency in 1995-2011. The second group consists of the gminas where the ANR sold 2/3 of the land in question. In the second group of gminas, the ANR sold the land of the highest median value determined for the area of the sold arable land.

Table 4

Characteristics of the groups of gminas selected by means of Ward's method.

\begin{tabular}{ccccccccc}
\hline \multirow{2}{*}{$\begin{array}{c}\text { Group } \\
\text { of } \\
\text { gminas }\end{array}$} & $\begin{array}{c}\text { Number } \\
\text { of } \\
\text { gminas }\end{array}$ & $\begin{array}{c}\text { Total sold } \\
\text { area }\end{array}$ & $\begin{array}{c}\text { Median of } \\
\text { arable land } \\
\text { area }\end{array}$ & $\begin{array}{c}\text { Mean area of } \\
\text { arable land }\end{array}$ & $\begin{array}{c}\text { Median of } \\
\text { woodland } \\
\text { area }\end{array}$ & $\begin{array}{c}\text { Mean area } \\
\text { of woodland }\end{array}$ & $\begin{array}{c}\text { Median of } \\
\text { shrubland area }\end{array}$ & $\begin{array}{c}\text { Mean area of } \\
\text { shrubland }\end{array}$ \\
\hline I & 46 & 60515 & 912 & 913 & 210 & 101 & 17 & 22 \\
\hline II & 41 & 126025 & 2374 & 2462 & 262 & 190 & 33 & 36 \\
\hline III & 24 & 4984 & 91 & 155 & 24 & 10 & 1 & 3 \\
\hline
\end{tabular}

Source: own study based on the ANR database.

\section{Selected methods of testing the stability of structures}

In order to define the stability of the structure of the cultivated parts of agricultural real estate sold in the subsequent years, one can use a simple measure of structure variation (ZAJĄC 1982):

$$
V=\frac{\sum_{i=1}^{k}\left|\alpha_{i t}-\alpha_{i(t+1)}\right|}{2}
$$

where:

$$
\begin{array}{ll}
\alpha_{i t} & \text { - the share of the } \mathrm{i} \text {-th component in the period preceding the period of study, } \\
\alpha_{i(t+1)} & \text { - the share of the } \mathrm{i} \text {-th component in the period of study, } \\
\mathrm{i}=1,2, \ldots, \mathrm{k} & \text { - subsequent components of the structure, } \\
\mathrm{t}=0,1, \ldots \mathrm{m} & \text { - subsequent years in the period of study. }
\end{array}
$$

The values of the structure variation measures are within the interval $\langle 0 ; 1\rangle$, where an index value close to zero signifies a weaker structure variation, while a strong variation is characterized by values closer to one. 
Another simple method of comparing structures is a relative structure comparison index built on the basis of structure indices (DOMAŃSKI 2001).

$$
W_{p . s t r .}=\frac{\sum_{i=1}^{k} \min \left(W_{i 1}, W_{i 2}\right)}{\sum_{i=1}^{k} \max \left(W_{i 1}, W_{i 2}\right)}
$$

where:

$W_{i 1}, W_{i 2}$ - the structure index of the subject of study in comparable units.

The closer that the relative structure comparison index is to one, the more similar the compared structures.

Table 5

Dynamics of the structure of land sold by the ANR in Szczecin in the Zachodniopomorskie voivodeship in 1995-2011 (\%).

\begin{tabular}{|c|c|c|c|c|c|c|c|c|c|}
\hline \multirow{2}{*}{ Type of land } & \multicolumn{9}{|c|}{ Years of study } \\
\hline & 1995 & 1996 & 1997 & 1998 & 1999 & 2000 & 2001 & 2002 & 2003 \\
\hline Arable land & 67.62 & 70.75 & 73.45 & 73.57 & 68.24 & 73.19 & 69.77 & 73.89 & 71.87 \\
\hline Orchards & 4.55 & 2.09 & 2.68 & 1.19 & 1.07 & 1.06 & 2.59 & 2.65 & 2.33 \\
\hline Meadows & 8.75 & 10.05 & 8.94 & 8.36 & 10.48 & 12.36 & 10.92 & 7.94 & 10.51 \\
\hline Pastures & 8.31 & 8.35 & 7.32 & 9.14 & 10.18 & 5.68 & 8.19 & 7.52 & 9.12 \\
\hline Forests & 0.35 & 1.19 & 0.91 & 0.69 & 1.11 & 0.92 & 0.52 & 0.98 & 0.77 \\
\hline Shrubland & 1.97 & 0.81 & 1.06 & 1.83 & 2.96 & 1.77 & 1.48 & 1.97 & 1.22 \\
\hline Standing water & 0.48 & 0.32 & 0.28 & 0.59 & 0.97 & 0.70 & 1.13 & 0.50 & 0.01 \\
\hline Running water & 0.00 & 0.00 & 0.00 & 0.00 & 0.00 & 0.00 & 0.00 & 0.00 & 0.00 \\
\hline Ditches & 0.69 & 0.35 & 0.41 & 0.34 & 0.46 & 0.37 & 0.26 & 0.23 & 0.29 \\
\hline Wasteland & 7.27 & 6.10 & 4.94 & 4.30 & 4.53 & 3.95 & 5.15 & 4.32 & 3.88 \\
\hline Total & 100 & 100 & 100 & 100 & 100 & 100 & 100 & 100 & 100 \\
\hline $\begin{array}{l}\mathrm{V} \text { measure of } \\
\text { variation }\end{array}$ & - & 0.253 & 0.090 & 0.133 & 0.141 & 0.149 & 0.218 & 0.316 & 0.222 \\
\hline \multirow{2}{*}{ Type of land } & \multicolumn{9}{|c|}{ Years of study } \\
\hline & 2004 & 2005 & 2006 & 2007 & 2008 & 2009 & & 2010 & 2011 \\
\hline Arable land & 79.17 & 78.77 & 71.91 & 73.95 & 80.38 & 79.50 & & 79.14 & 77.72 \\
\hline Orchards & 0.09 & 0.16 & 0.57 & 0.19 & 0.46 & 0.12 & & 0.01 & 0.17 \\
\hline Meadows & 8.68 & 8.80 & 14.84 & 14.20 & 7.53 & 9.68 & & 8.69 & 10.02 \\
\hline Pastures & 5.67 & 5.82 & 6.43 & 4.79 & 5.44 & 4.29 & & 5.62 & 4.44 \\
\hline Forests & 1.45 & 1.70 & 1.10 & 1.77 & 1.54 & 1.42 & & 1.35 & 1.76 \\
\hline Shrubland & 0.94 & 1.19 & 1.34 & 1.41 & 1.12 & 1.35 & & 1.49 & 2.04 \\
\hline Standing water & 0.21 & 0.03 & 0.13 & 0.11 & 0.10 & 0.10 & & 0.01 & 0.06 \\
\hline Running water & 0.00 & 0.00 & 0.00 & 0.00 & 0.00 & 0.00 & & 0.00 & 0.00 \\
\hline Ditches & 0.40 & 0.41 & 0.68 & 0.71 & 0.37 & 0.41 & & 0.46 & 0.53 \\
\hline Wasteland & 3.39 & 3.12 & 3.00 & 2.88 & 3.05 & 3.14 & & 3.22 & 3.26 \\
\hline Total & 100 & 100 & 100 & 100 & 100 & 100 & & 100 & 100 \\
\hline $\begin{array}{l}\mathrm{V} \text { measure of } \\
\text { variation }\end{array}$ & 0.277 & 0.277 & 0.212 & 0.219 & 0.290 & 0.266 & & 0.275 & 0.259 \\
\hline
\end{tabular}

Source: own study based on the ANR database.

In the subsequent years, the determined variation measure of typical structures adopted low values ranging 0.09-0.316 (variation measure value $\mathrm{V}$ in Table 5), which means that the structures were poorly varied in time, i.e., the structures of cultivated land sold as parts of agricultural real estate were stable in the analyzed years. The most similar structures of land were observed in 2004 and 2005 as well as in 1995 and 1997, while the least similar - in 2008. 


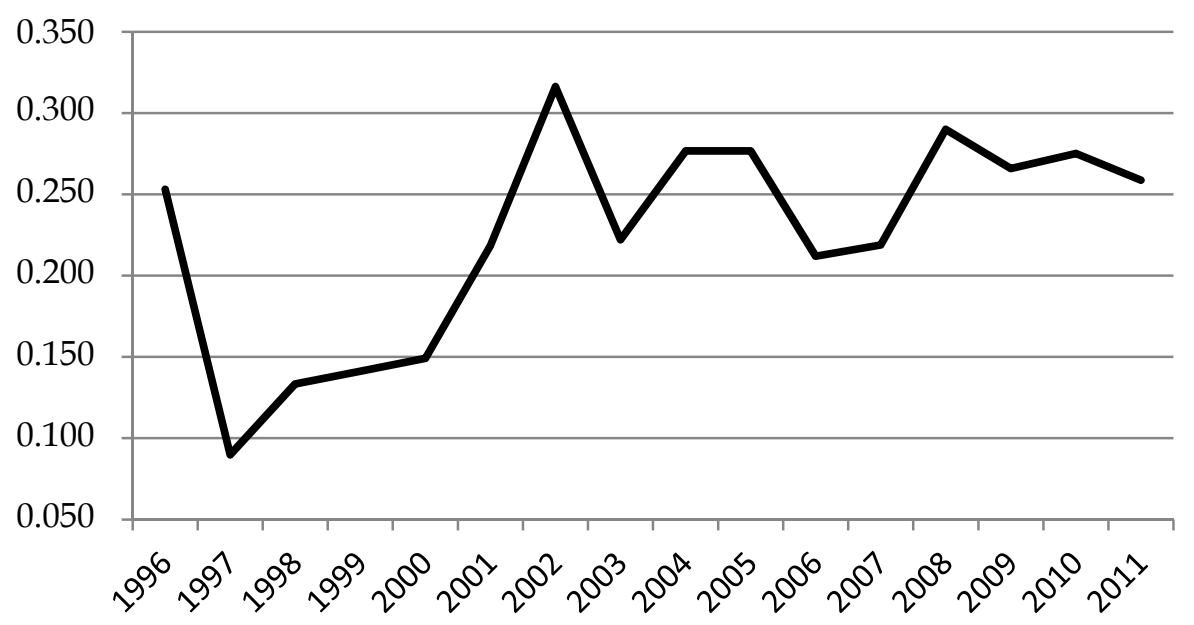

Fig.3. Values of the structure variation index in 1995-2011. Source: own study based on the ANR database.

The values of the relative index of structure comparison were determined by means of formula 2 . The obtained values ranged from 0.519 to 0.835 , which confirms the fact that the compared structures are similar (Table 6). The highest value of the relative structure comparison index was obtained in 1997 (0.835), while the lowest value was observed in 2002 (0.519), which indicates the least similar structures, just as in the case of using formula 1.

Table 6

Values of the relative index of structure comparison.

\begin{tabular}{lrrrrrrrr}
\hline Years & $\mathbf{1 9 9 6}$ & $\mathbf{1 9 9 7}$ & $\mathbf{1 9 9 8}$ & $\mathbf{1 9 9 9}$ & $\mathbf{2 0 0 0}$ & $\mathbf{2 0 0 1}$ & $\mathbf{2 0 0 2}$ & $\mathbf{2 0 0 3}$ \\
\hline$W_{\text {p.str. }}$ & 0.596 & 0.835 & 0.765 & 0.753 & 0.740 & 0.641 & 0.519 & 0.636 \\
\hline years & $\mathbf{2 0 0 4}$ & $\mathbf{2 0 0 5}$ & $\mathbf{2 0 0 6}$ & $\mathbf{2 0 0 7}$ & $\mathbf{2 0 0 8}$ & $\mathbf{2 0 0 9}$ & $\mathbf{2 0 1 0}$ & $\mathbf{2 0 1 1}$ \\
\hline$W_{\text {p.str. }}$ & 0.567 & 0.566 & 0.650 & 0.641 & 0.550 & 0.580 & 0.568 & 0.589 \\
\hline
\end{tabular}

Source: own study based on the ANR database.

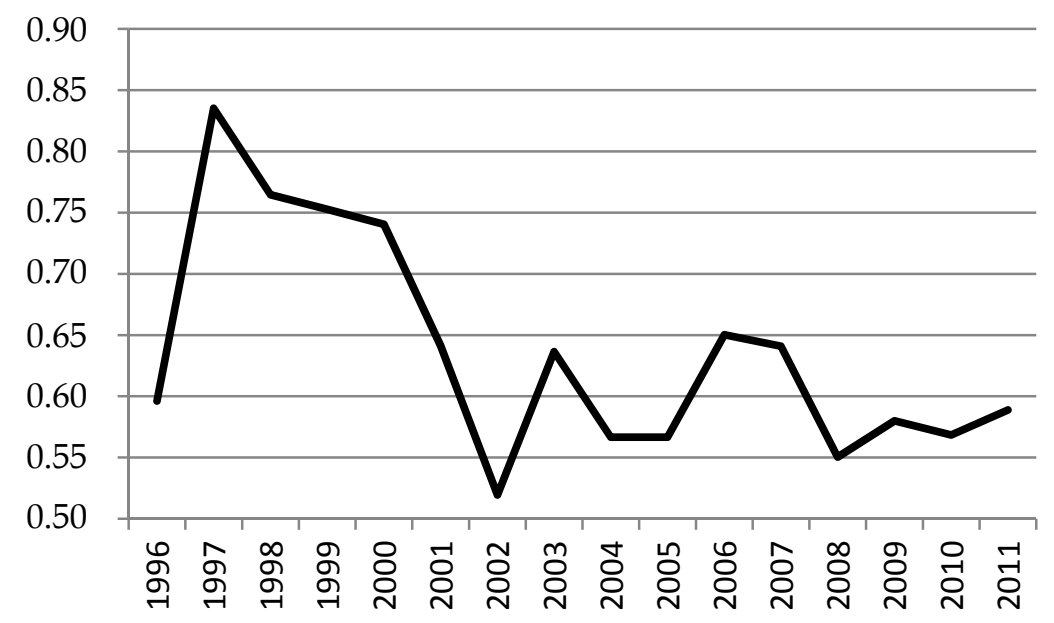

Fig.4. Values of the relative structure variation index in 1995-2011. Source: own study based on the ANR database.

As the next step, the authors employed the gmina clustering they had performed earlier and conducted an analysis of the sold land structure typical of a given group. In each of the three groups of gminas and in each group of transactions, they determined the medians of the share that the individual types of cultivated land had in the total area of the sold real estate for each type of cultivated land, over the entire study period. 
The results presented in Table 7 can be defined as a typical structure of cultivated land sold by the ANR in the analyzed area. The determined medians of the proportion of individual types of cultivated land in a given group of gminas do not add up to 100.

Table 7

Medians of the proportion of individual types of cultivated land in agricultural properties sold in the Zachodniopomorskie voivodeship by the ANR in Szczecin in 1995-2011(\%).

\begin{tabular}{lccc}
\hline Type of land & Group 1 & Group 2 & Group 3 \\
\hline arable land & 73.00 & 82.19 & 79.41 \\
\hline orchards & 0.03 & 0.04 & 0.00 \\
\hline meadows & 9.09 & 6.92 & 10.15 \\
\hline forests & 0.96 & 1.37 & 0.71 \\
\hline wooded land & 1.25 & 1.05 & 0.91 \\
\hline standing water & 0.00 & 0.03 & 0.00 \\
\hline running water & 0.00 & 0.00 & 0.00 \\
\hline ditches & 0.51 & 0.29 & 0.30 \\
\hline roads & 0.05 & 0.07 & 0.00 \\
\hline wasteland & 2.37 & 3.28 & 2.10 \\
\hline $\begin{array}{l}\text { V measure of variation } \\
\text { (min) }\end{array}$ & 0.05 & 0.01 & 0.02 \\
\hline $\begin{array}{l}\text { V measure of variation }( \\
\text { max) }\end{array}$ & 0.64 & 0.21 & 0.6 \\
\hline$W_{\text {p.str. }}$ & 0.07 & 0.40 & 0.02 \\
\hline
\end{tabular}

Source: own study based on the ANR database.

The median of the proportion of arable land in the area of traded land is the lowest in the first group, i.e., in the group of gminas with the lowest soil class $(73 \%)$ and the highest in the second group of gminas with the best classes of soil $(82.19 \%)$. Although the typical structure of cultivated land in the individual groups of gminas is not identical, we can observe a significant proportion of arable land and meadows.

When we adopt the maximum as the measure of variation, we obtain higher values in the first and third group, which points to stronger variation over time in the analyzed structures in those groups than in the second. Despite of this, the indices in all the groups are low, which indicates poor structure variation. Adopting the minimum as the measure of variation indicates weak variation of structures in each of the groups in the analyzed years. The obtained dependencies can be confirmed by the structure comparison index, defined by means of formula 2.

\section{Conclusions}

The authors of this paper aimed to verify the research hypothesis regarding the stability over time of the structure of cultivated land which was a part of the State Treasury real estate sold by the ANR in Szczecin. With this purpose in mind, they applied simple measures of structure variation and a relative index of structure comparison which help to evaluate the stability of a given structure over time. The results of comparing structure variation measured by means of different methods can be found in Tables 8 and 9.

Table 8

Measures of variation of the structure of cultivated land sold in the Zachodniopomorskie voivodeship by the ANR in Szczecin in 1995-2011.

\begin{tabular}{lccccccccc}
\hline & \multicolumn{8}{c}{ Years of study } \\
\cline { 2 - 9 } \multicolumn{1}{c}{ Type of index } & $\mathbf{1 9 9 5}$ & $\mathbf{1 9 9 6}$ & $\mathbf{1 9 9 7}$ & $\mathbf{1 9 9 8}$ & $\mathbf{1 9 9 9}$ & $\mathbf{2 0 0 0}$ & $\mathbf{2 0 0 1}$ & $\mathbf{2 0 0 2}$ & $\mathbf{2 0 0 3}$ \\
\hline $\begin{array}{l}\text { V measure of } \\
\text { variation } \\
\text { by formula 1 }\end{array}$ & - & 0.253 & 0.090 & 0.133 & 0.141 & 0.149 & 0.218 & 0.316 & 0.222 \\
\hline
\end{tabular}




\begin{tabular}{|c|c|c|c|c|c|c|c|c|c|}
\hline $\begin{array}{l}W_{\text {p.str. }} \\
\text { by formula } 2\end{array}$ & & 0.596 & 0.835 & 0.765 & 0.753 & 0.740 & 0.641 & 0.519 & 0.636 \\
\hline \multirow{2}{*}{ Type of index } & \multicolumn{9}{|c|}{ Years of study } \\
\hline & 1995 & 2004 & 2005 & 2006 & 2007 & 2008 & 2009 & 2010 & 2011 \\
\hline $\begin{array}{l}\text { V measure of } \\
\text { variation } \\
\text { by formula } 1\end{array}$ & \multirow[t]{2}{*}{ - } & 0.277 & 0.277 & 0.212 & 0.219 & 0.290 & 0.266 & 0.275 & 0.259 \\
\hline $\begin{array}{l}W_{\text {p.str. }} \\
\text { by formula } 2\end{array}$ & & 0.567 & 0.566 & 0.650 & 0.641 & 0.550 & 0.580 & 0.568 & 0.589 \\
\hline
\end{tabular}

Source: own study based on the ANR database.

Table 9

Measures of variation of the structure of cultivated land sold in the Zachodniopomorskie voivodeship by the ANR in Szczecin in 1995-2011 (by groups of gminas).

\begin{tabular}{lccc}
\hline \multicolumn{1}{c}{ Type of index } & Group 1 & Group 2 & Group 3 \\
\hline $\begin{array}{l}\text { V measure of variation } \\
(\text { min) by formula 1 }\end{array}$ & 0.05 & 0.01 & 0.02 \\
\hline $\begin{array}{l}\text { V measure of variation } \\
(\max ) \text { by formula 1 }\end{array}$ & 0.64 & 0.21 & 0.6 \\
\hline $\begin{array}{l}W_{\text {p.str. }} \\
\text { by formula 2 }\end{array}$ & 0.07 & 0.40 & 0.02 \\
\hline
\end{tabular}

Source: own study based on the ANR database.

The State Treasury real estate in the Zachodniopomorskie voivodeship sold by the ANR is characterized by a structure of cultivated land which is stable over time, as confirmed by low values of structure variation measures (Table 8). In addition, the study was supplemented with the spatial analysis of cultivated land traded by the ANR. When looking into the structure and prices of the sold land, the clustering of the gminas of the Zachodniopomorskie voivodeship into three groups resulted in land structure variation that was larger than if the clustering had not been performed (Table 9). The effect of clustering, due to the chosen characteristics, enabled the authors to distinguish the groups of gminas that were similar in terms of the share of arable land in the real estate sold locally by the ANR and to associate these characteristics with a particular location in the Zachodniopomorskie voivodeship.

In conclusion, the above presented study set the path for further research, particularly for an attempt at a deeper analysis of the structures and their stability over time performed on a larger group of gminas - seven or nine (Fig. 2). It can also help to search for relationships, not only between the obtained transaction prices and structures of traded land, but also between other important factors which locally affect the value of the above analyzed real estate.

\section{Bibliography}

BLAUG M., 1994, Teoria ekonomii. Ujęcie retrospektywne, PWN, Warszawa.

CYMERMAN R. I INNI, 2011, Podstawy rolnictwa wycena nieruchomości rolnych, Educaterra, Olsztyn.

DOMANSKI Cz., 2001, Metody statystyczne. Teoria i zadania, Wydawnictwo Uniwersytetu Łódzkiego, Łódź.

GATNAR E., WALESIAK M., 2004, Metody statystycznej analizy wielowymiarowej w badaniach marketingowych, Wydawnictwo Akademii Ekonomicznej, Wrocław.

FORYŚ I., 2005, Renta gruntowa w teorii ekonomii, w: Wybrane problemy polskiego rolnictwa, IADiPG, Szczecin.

HOZER J. I INNI, 1999, Ekonometryczny algorytm masowej wyceny nieruchomości gruntowych, Stowarzyszenie Pomoc i Rozwój, Szczecin.

KONOWALCZUK J., URBAŃCZYK K., 2000, Podstawy teoretyczne i metodyczne wyceny nieruchomości rolnych, w: Wycena nieruchomości rolnych, PFSRzM, WARSZAWA.

Rocznik statystyczny województw, Urząd Statystyczny w Szczecinie, Szczecin 2011. 
ZAJAC K., 1982, Zarys metod statystycznych, PWE, Warszawa.

Użytkowanie gruntów, powierzchnia zasiewów i pogłowie zwierząt gospodarskich w województwie zachodniopomorskim. Powszechny Spis Rolny 2010, Urząd Statystyczny w Szczecinie, Szczecin 2013. 